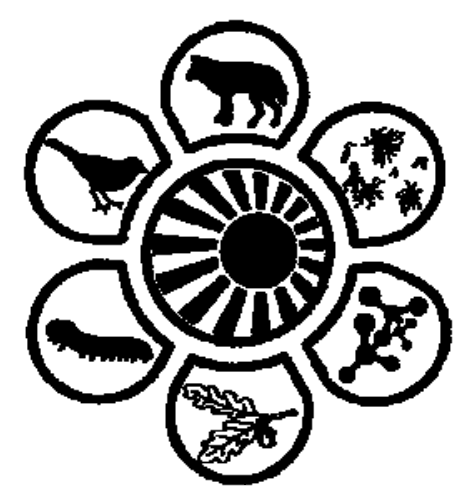

Вісник Дніпропетровського університету. Біологія, екологія.

Vìsnik Dnìpropetrovs'kogo unìversitetu. Seriâ Bìologiâ, ekologiâ

Visnyk of Dnipropetrovsk University. Biology, ecology.

Vìsn. Dnìpropetr. Unìv. Ser. Bìol. Ekol. 2015. 23(2), 216-220.

doi:10.15421/011531

ISSN 2310-0842 print

ISSN 2312-301X online

www.ecology.dp.ua

УДК 599:574.4+577.15

\title{
Вплив екскрецій Capreolus capreolus i Sus scrofa на активність аланінамінотрансферази в листках Glechoma hederacea в умовах забруднення кадмієм
}

\author{
О.М. Василюк, О.С. Пахомов \\ Дніпропетровський наиіональний університет імені Олеся Гончара, Дніпропетровськ, Украйна
}

Досліджено активність (нМ піровиноградної кислоти/мл·с) ферменту азотного метаболізму аланінамінотрансфераза (ALT, EC 2.6.1.2) та вміст альбумінів (мг/мл) у листках Glechoma hederacea L., яка домінувала на дослідній території (липово-ясенева діброва зі Stellaria holostea L.) на фоні солей Cd, екскретів ссавців Capreolus capreolus L. та Sus scrofa L. та їх спільної дії. $\mathrm{Cd}$ вносили у вигляді солі $\mathrm{Cd}\left(\mathrm{NO}_{3}\right)_{2}$ у концентраціях $0,25,1,25$, та 2,50 г/м², що еквівалентно 1,5 та 10 ГДК Сd. При внесенні враховували кількість ГДК для Сd (5 мг/кг грунту). Виявлено достовірне інгібіювання активності АЛТ у 3-4 рази (на фоні 1 та 5 ГДК $\mathrm{Cd}$ ). Подібний відгук на стрес відбувався й у білковому метаболізмі. Визначено достовірне зниження вмісту альбумінів до $72 \%$ та 80\% (на фоні 1 та 5 ГДК Сd) відносно контролю (ділянка без забруднення Сd та екскретів ссавців), що доводить неспецифічність реакції на стрес. Використання екскрементів C. capreolus та S. scrofa показало нівелювання впливу Сd за рахунок підвищення активності метаболізму АЛТ на 41\% та 105\% відповідно (на фоні 1 ГДК Сd) відносно контролю (контроль 1 ГДК Сd). Дія Сd у дозі 5 ГДК достовірно відносно контролю (контроль 5 ГДК Сd) нівельована тільки на фоні екскрементів C. capreolus. Виявлено нормалізацію вмісту альбумінів при залученні екскрементів C. capreolus при 1 та 5 ГДК Сd відносно контролів. За умов 10 ГДК Сd інгібіювався нітратний обмін на 50\% на фоні екскретів як C. capreolus, так і S. scrofa відносно контролю (контроль 10 ГДК Сd). Екскреції $S$. scrofa порівняно із C. capreolus сприяли відновленню на $10 \%$ вмісту альбумінів відносно контролю. 3 'ясовано доцільність використання різних представників зооценозу для комплексного регулювання змін навколишнього середовища в умовах Степу України.

Ключові слова: водорозчинна фракція білка; важкі метали; ссавці; гранично допустима концентрація; антропогенний стрес

\section{Effect of Capreolus capreolus and Sus scrofa excreta on alanine aminotransferase activity in Glechoma hederacea leaves in conditions of $\mathrm{Cd}$ pollution}

\author{
O.M. Vasilyuk, O.Y. Pakhomov
}

\section{Oles Honchar Dnipropetrovsk National University, Dnipropetrovsk, Ukraine}

The paper reflects the analysis of Cd impact on the total activity (nM pyruvic acid/ml s) of alanine aminotransferase (ALT, EC 2.6.1.2) nitrogen metabolism and the content $(\mathrm{mg} / \mathrm{ml})$ of water-soluble protein fraction (albumin) in Glechoma hederacea $\mathrm{L}$. leaves subject, which dominated in the research area (natural floodplain oak with Stellaria holostea L.). Cd was introduced in the form of salts $\mathrm{Cd}\left(\mathrm{NO}_{3}\right)_{2}$ in the concentrations of $0.25,1.25$ and $2.50 \mathrm{~g} / \mathrm{m}^{2}$, equivalent to $\mathrm{Cd}$ in 1,5 and 10 doses of MAC. The content of doses of MAC of Cd (5 mg/kg soil) was taken into account during introduction. We observed the inhibition of the activity of ALT 3-4 times (with adding the Cd salts at a dose of 1 and $5 \mathrm{MAC}$ ) compared to controls (area without pollution of $\mathrm{Cd}$ and excreta of mammals). This stress reaction took place in the protein complex as well. Thus, albumin content was equal to $72 \%$ and $80 \%$ (with $\mathrm{Cd} 1$ and $5 \mathrm{MAC}$ ) compared to control (the area without pollution and excretory functions of mammals). It proved nonspecific response to stress. Using excreta of Capreolus capreolus L. and Sus scrofa $\mathrm{L}$. shows the reduction of Cd effects and increasing the metabolic activity of ALT by $41 \%$ and $105 \%$, respectively (with adding of Cd $1 \mathrm{MAC}$ ) compared to control (pollution by $\mathrm{Cd}$ at a dose $1 \mathrm{MAC}$ ). The effect of $\mathrm{Cd} 5 \mathrm{MAC}$ is offset (only with the introduction of C. capreolus excreta) compared to control (pollution by $\mathrm{Cd}$ at a dose $5 \mathrm{MAC}$ ). Normalization of the albumin content (with adding of $\mathrm{Cd}$ 1 and 5 MAC) compared to control (control of $\mathrm{Cd}$ at a dose $1 \mathrm{MAC}$ and control of $\mathrm{Cd}$ at a dose 5 MAC) with using of excreta of

Дніпропетровський національний університет імені Олеся Гончара, пр. Гагаріна, 72, Дніпропетровськ, 49010, Україна Oles Honchar Dnipropetrovsk National University, Gagarin Ave., 72, Dnipropetrovsk, 49010, Ukraine

Тел.:+38-093-358-07-45.E-mail: vasilyuk.elena@mail.ru 
C. capreolus was observed. In conditions of $\mathrm{Cd}$ at a doze $10 \mathrm{MAC}$ the ALT activity was reduced 2 times with the introduction of excreta of C. capreolus as $S$. scrofa compared to control (Cd at a dose $10 \mathrm{MAC}$ ). The introduction of excreta of S. scrofa compared with C. capreolus restored the albumin content by $10 \%$ to the control. Thus, the feasibility of using different biological community representatives for comprehensive regulation of the environmental changes in the conditions of steppe Ukraine has been found.

Keywords: water-soluble protein fraction; heavy metal; mammals; maximum allowable concentration; anthropogenic stress

\section{Вступ}

Екологічні (абіотичні, біотичні та антропогенні) чинники суттєво впливають на тваринні та рослинні організми, їх фізіологічні, морфометричні та біохімічні показники в динаміці росту та розвитку. Важкі метали (BM), як потужні та поширені полютанти антропогенного походження, масштабно впливають на всі складові біоти: мікробоценоз, зооценоз, фітоценоз. В осьових органах кукурудзи екзогенний $\mathrm{Cd}$ у концентраціях $10^{-8}, 10^{-7}, 10^{-6} \mathrm{M}$ токсичний, індукує зростання кількості фенольних сполук, вільного проліну (Pr) відносно вмісту вільних амінокислот (Kobyletska and Terek, 2002). Boshoff et al. (2014) порівняли особливості вегетації та накопичення As, Cd, Cu, Pb та Zn у траві Agrostis sp./Poa sp. та Urtica dioica L., що росли у грунтах із широким діапазоном забруднення ВМ і значним варіюванням властивостей. Запропоновано версію генетичного різноманіття у Viola reichenbachiana Jord. ex Boreau та $V$. riviniana Reichenb., які зростають на грунтах із різним вмістом ВM (Kuta et al., 2014).

Hameed et al. (2011) надали відомості стосовно того, що солі $\mathrm{CdCl}_{2}$ та $\mathrm{HgCl}_{2}$ залежно від концентрації індукували різну відповідь ферментів антиоксидантного захисту (AO3), пов'язаних із постійною детоксикацією $\mathrm{H}_{2} \mathrm{O}_{2}$ : аскорбатпероксидази (АРХ, ЕС 1.11.1.11), каталази (CAT, ЕC 1.11.1.6), глутатіонредуктази (GR, EC 1.6.4.2). супероксиддисмутази (SOD, EC 1.15.1.1) у Abelmoschus esculentus L., адаптованої до виживання у стресових умовах. Wang et al. (2010) визначили механізми детоксикації $\mathrm{Pb}, \mathrm{Zn}, \mathrm{Cu}, \mathrm{Cd}$ у саджанцях Paulownia fortunei (Seem.) Hemsl та вплив BM на термін проростання, довжину коренів, вміст пігментів. 3'ясовано ефективний механізм детоксикації $\mathrm{Pb}$ та $\mathrm{Cd}$ за рахунок активації ферментів АO3, фітохелатування та підвищення вмісту $\mathrm{Pr}$. Навіть у низьких концентраціях $\mathrm{Cu}$ загрожувала росту та розвитку саджанців. Hasan et al. (2011) досліджували позитивний та токсичний ефект Со на п'яти сортах томату за реакцією ферментів АO3 на стрес: пероксидази (РХ, ЕС 1.11.1.7), каталази, СОД, нітрат-редуктази (NR, EC 1.6.6.1), карбоангідрази (ЕC 4.2.1.1), за вмістом Pr та за впливом на фотосинтез деяких сільськогосподарських рослин. Щодо стійкості до Со сорти томатів розташовані таким чином: К-25 > NTS $>$ NBR-Uday $>$ Sarvodya $>$ Malti.

Joshi et al. (2011) визначили роль групи органічних речовин (етрелу та нафталіноцтової кислоти), деяких регуляторів рослин (РРP) на морфометричні (висота рослини, кількість суцвіть, кількість чоловічих та жіночих квіток у суцвітті та їх співвідношення) та біохімічні показники (вміст хлорофілів та $\mathrm{Pr}$, активність NR) у рослини Jatropha curcas L. Автори показали пряму кореляцію між синергізмом органічних речовин (ауксином, етиленом) та концентрацією РРР.

Rau et al. (2007) дослідили чутливість Fontinalis antipyretica Hedw. до $\mathrm{BM}(\mathrm{Cu}, \mathrm{Cd}, \mathrm{Zn}, \mathrm{Pb})$ на рівні біохімічних реакцій (хлорофільна флуоресценція, внутріклітинна локалізація ВМ та рівень стресових білків). Відбулось зниження флуоресценції хлорофілу та індукція стресових білків у водяного моху на фоні підвищення внутрішньоклітинної локалізації ВМ.

На забруднених ВМ територіях Wu et al. (2010) розрахували металоакумуляцію (94,7 мг/кг As, 417 мг/кг Pb, 498 мг/кг Zn, 5,8 мг/кг Cd, 27,7 мг/кг Cu) та виявили ендомікоризний статус у коренях Cynodon dactylon (L.) Pers., що колонізований грибами роду Acaulospora (Gerdemann and Trappe, 1974) та Glomus (Tul. and C. Tul., 1845). Знайдено 82 спори на 25 г забрудненого грунту та 371 спору на 25 г незабрудненого грунту, тоді як мікробіологічне різноманття було значно вищим для інтенсивніше забруднених грунтів. Дані дослідження доцільно використовувати для фітовідновлення на металозабруднених територіях толерантних до грибів видів рослин.

Вплив Сd вивчали і на тваринних об'єктах. Sheryl et al. (2011) дослідили вплив $\mathrm{Cu}$ та $\mathrm{Cd}$ на фагоцитоз у Eisenia hortensis (Michaelsen, 1890), на здатність гіалінових амебоцитів поглинати флуоресцентні кишкові палички, що доцільно використовувати для тестування токсикологічних наслідків впливу екологічних забруднювачів, використовуючи целомоцити дощового черва як індикатор окисного стресу та порушення імунної відповіді. Song et al. (2014) виявили ефект дії $\mathrm{Cu}$ та Cd (як поодинока, так і комплексна експозиція) на виді риби Synechogobius hasta (Temminck et Schlegel, 1845) у Китаї, Японії та Кореї. Li et al. (2014) визначили ефект генної експресії на оксигенний стрес в ендемічного виду риби Gobio cypris rarus (M.R. Ye and T.Y. Fu, 1983) у Китаї.

Has-Schön et al. (2015) порівняли розподіл та біоакумуляцію $\mathrm{Pb}, \mathrm{Cd}$, As та $\mathrm{Hg}$ у тканинах озерних риб Cyprinus carpio haematopterus (Temminch et Schlegel, 1842) та Sylurus glanis (Linnaeus, 1758) з Боснії та Герцеговини. Концентрація Аs була нижчою за ГДК (Хорватія та ін.), вміст $\mathrm{Hg}$ становив менше 1 мг/кг. У м'язах зразків обох видів риб та в усіх зразках печінки сома вміст Hg був вищим 0,5 мг/кг (вище показників ГДК для Хорватії та інших країн). Вміст $\mathrm{Pb}$ у більшості зразків м'язів був вищим 1 мг/кг (показник ГДК Хорватії); у більшості зразків печінки сома вміст Нg був таким самим. Концентрація Сd в усіх тканинах, крім гонад, була вища 0,1 мг/кг (ГДК для Хорватії) із підвищенням концентрації у мальків. Гендерні відмінності спостерігали тільки у коропа, де концентрація Аs була на $68 \%$ вищою в ікрі, ніж у молоках. Концентрація усіх інших елементів підвищена у сома порівняно з коропом у більшості видів тканин. Автори зареєстрували достовірну кореляцію між усіма даними елементами у м'язах та печінці коропа. Достовірна акумуляція ВМ коропом і сомом корелювала 3 віком та масою тіла. Видова та тканинна біоакумуляція специфічна та відрізняється для кожного з елементів. 
У субтропічних мангрових устриць Crassostrea corteziensis (Hertlein, 1951) з’ясовано (Páez-Osuna, 2015) біодоступність $\mathrm{Cd}, \mathrm{Hg}, \mathrm{Cu}, \mathrm{Pb}$ та Zn. Shamim et al. (2014) дослідили вплив $\mathrm{Cd}$ i на деяких представників дроб'янок (Cupriavidus metallidurans $\mathrm{CH} 34$ та Pseudomonas putida $\mathrm{mt2}$ ). На забруднених BM грунтах Weyens et al. (2014) також визначили бактеріальну асоціацію люпину та оцінили ії потенціал для підвищення Cd-фітоекстракції.

Значний внесок у захист та відновлення довкілля за умов антропогенного навантаження забезпечують біотичні чинники з використанням ферментативної системи білкового обміну (Vasilyuk and Pakhomov, 2012, 2014). Біотичні чинники (екскреторна та рийна активність ссавців) відіграють середовищетвірну роль в умовах неконтрольованої діяльності людини. Середовищетвірна активність тварин - опосередкований чинник в умовах антропогенного впливу на довкілля. Мета цієї статті виявити із застосуванням біохімічних методів (активність ферментів азотного метаболізму та вміст альбумінів) вплив екскрецій Sus scrofa L. та Capreolus capreolus L. на фоні дії солей $\mathrm{Cd}$.

\section{Матеріал і методи досліджень}

Досліди проводили в умовах Присамарського міжнародного біосферного стаціонару імені О.Л. Бельгарда. Як контроль обрано територію, не забруднену $\mathrm{Cd}$ (липово-ясенева діброва із зірочником ланцетолистим (Stellaria holostea L.)) та в умовах забруднення грунтів солями $\mathrm{Cd}\left(\mathrm{Cd}\right.$ вносили у грунт у вигляді $\mathrm{Cd}\left(\mathrm{NO}_{3}\right)_{2}$ у концентраціях $0,25,1,25$ та 2,50 г/ $\mathrm{M}^{2}$, що еквівалентно $\mathrm{Cd}$ у дозі 1,5 та 10 ГДК). Для запобігання забруднення шарів грунту Cd були використані ізольовані на глибину 20 см грунтові блоки. При внесенні враховано ГДК для $\mathrm{Cd}-5$ мг/кг грунту. Визначено загальну (Polevoy and Maximov, 1978) активність аланінамінотрансферази (ALT, EC 2.6.1.2; нМ піровиноградної кислоти/мл·с) i концентрацію (мг/мл) водорозчинної фракції білка (Bradford, 1976) як індикаторів екологічного стану довкілля. АЛТ та аспартатамінотрансфераза (AST, EC 2.6.1.1) є частиною ферментативної системи, за допомогою якої утилізується первинний продукт фотосинтезу $\mathrm{C}_{4}$ групи рослин - аспартат, який синтезується у мезофілі листка та направляється до клітин обкладинки судинних пучків (Polevoy and Maximov, 1978). За допомогою АСТ у клітинах обкладинки судинних пучків листка відбувається декарбоксилювання аспартату, що утворився у мезофілі листка, до піровиноградної кислоти та діоксиду карбону. Піруват амінується за допомогою АЛТ до аланіну і повертається до мезофілу листка, де дезамінується за участю того самого АЛТ. У роботі достовірною вважали відмінність між дослідним варіантом та контролем за $\mathrm{P}<0.05$ (Dospekhov, 1985).

Вплив екскрецій ссавців визначали на прикладі внесення екскрецій $S$. scrofa та C. capreolus. Біохімічні показники визначали через місяць у листках Glechoma hederacea L., яка домінувала на дослідній території, за такою схемою:

1) дія тільки солей $\mathrm{Cd}$ : контроль (ділянка без забруднення $\mathrm{Cd}$ та без екскрецій ссавців), дослід 1 ГДК $\mathrm{Cd}$, дослід 5 ГДК Сd;
2) комбінована дія солей $\mathrm{Cd}$ та екскрецій $C$. capreolus та S. scrofa: контроль 1 ГДК Cd, вплив 1 ГДК Сd на фоні екскрецій $S$. scrofa, вплив 1 ГДК Сd на фоні екскрецій C. capreolus, контроль 5 ГДК Сd, вплив 5 ГДК Сd на фоні екскрецій $S$. scrofa, вплив 5 ГДК Сd на фоні екскрецій C. capreolus, контроль 10 ГДК $\mathrm{Cd}$, вплив 10 ГДК Сd на фоні екскрецій S. scrofa, вплив 10 ГДК Cd на фоні екскрецій C. capreolus.

\section{Результати та їх обговорення}

Визначено достовірне $\left(\mathrm{t}_{0,05}=3,59\right.$ та 2,59) зниження активності АЛТ у листках $G$. hederacea $L$. у 3-4 рази у разі збільшення концентрації $\mathrm{Cd} 31$ до 5 ГДК відносно контролю (ділянка без забруднення $\mathrm{Cd}$ та без екскрецій ссавців). Уміст водорозчинної фракції білків був достовірно $\left(\mathrm{t}_{0.05}=1,64,1,96\right.$ та 2,41$)$ нижчим відносно контролю (ділянка без забруднення $\mathrm{Cd}$ та без екскретів ссавців) за умови внесення $\mathrm{Cd}$ у дозі 1 та 5 ГДК та становив $72 \%$ та $80 \%$ від контролю (табл. 1).

Таблиия 1

Вплив Cd на загальну активність аланінамінотрансферази та концентрацію водорозчинної фракції білків у листках $G$. hederacea

\begin{tabular}{|c|c|c|c|}
\hline Показники & Варіант досліду & $\mathrm{x} \pm \mathrm{SD}$ & $\begin{array}{c}\text { Дослід/ } \\
\text { контроль, \% }\end{array}$ \\
\hline \multirow{3}{*}{ АЛТ } & $\begin{array}{l}\text { контроль (ділянка без } \\
C d \text { та екскрецій ссавців) }\end{array}$ & $1,61 \pm 0,179$ & - \\
\hline & 1 ГДК Cd & $0,41 \pm 0,041^{*}$ & 25,0 \\
\hline & 5 ГДК Cd & $0,62 \pm 0,109^{*}$ & 38,2 \\
\hline \multirow{3}{*}{$\begin{array}{c}\text { Водо- } \\
\text { розчинна } \\
\text { фракція - } \\
\text { білка }\end{array}$} & $\begin{array}{l}\text { контроль (ділянка без } \\
C d \text { та екскрецій ссавців) }\end{array}$ & $1,82 \pm 0,115$ & - \\
\hline & 1 ГДК Cd & $1,46 \pm 0,035^{*}$ & 80,1 \\
\hline & 5 ГДК $C d$ & $1,33 \pm 0,076^{*}$ & 72,9 \\
\hline
\end{tabular}

Примітки: $\mathrm{x}$ - середнє значення, SD - стандартне відхилення; * - достовірність відмінності між дослідним варіантом та контролем $\mathrm{P}<0,05$.

За умов комбінованої дії зоогенних (екскреції ссавців) та антропогенних (додавання $\mathrm{Cd}$ ) чинників визначили достовірне $\left(\mathrm{t}_{0,05}=1,61\right.$ та 2,53) підвищення на $41 \%$ активності АЛТ в листках $G$. hederacea порівняно з контролем (контроль 1 ГДК Сd) за рахунок впливу екскрецій $S . \quad$ scrofa та на $105 \%$ - завдяки екскреціям C. capreolus. У разі збільшення концентрації $\mathrm{Cd}$ до 5 ГДК відбулось достовірне зниження $\left(\mathrm{t}_{0,05}=1,11\right)$ нітратного обміну на 39\% відносно контролю (контроль 5 ГДК Сd) на фоні дії екскрементів $S$. scrofa та недостовірно $\left(\mathrm{t}_{0,05}=\right.$ 0,20) - на фоні дії C. capreolus.

За умов 10 ГДК Сd спостерігали інгібіювання $\left(\mathrm{t}_{0,05}=\right.$ $1,60$ та 1,54$)$ нітратного обміну та вмісту альбумінів на $50 \%$ на фоні екскретів як C. capreolus, так i $S$. scrofa відносно контролю (контроль 10 ГДК Сd). Активність АЛТ також достовірно $\left(\mathrm{t}_{0,05}=3,59,2,49,2,16,2,59,3,66\right.$ та 2,34) знижена у даному експерименті для всіх варіантів досліду відносно контролю (ділянка без забруднення $\mathrm{Cd}$ та без екскрецій Mammalia), тобто комбінована дія чинників все ж сприймається рослиною як подвійний стрес за умови дії даного металу (табл. 2).

За умов комбінованої дії кадмію та екскрецій змінювалась і концентрація водорозчинної фракції білка в лис- 
тках G. hederacea. За умов внесення 1 ГДК $\mathrm{Cd}$ на фоні дії екскрецій ссавців відбулось коливання (зниження/підвищення) нітратного обміну таким чином, що C. capreolus сприяла відновленню активності АЛТ до контрольних показників (контроль 1 ГДК Сd), відмінності між дослідним варіантом та контролем не були достовірними $\left(\mathrm{t}_{0,05}=0,10\right)$.

Таблиия 2

Вплив комбінованої дії екскрементів ссавців та Cd на загальну активність аланінамінотрансферази в листках $G$. hederacea

\begin{tabular}{|c|c|c|}
\hline Варіант досліду & $\mathrm{x} \pm \mathrm{SD}$ & $\begin{array}{c}\text { Дослід/ } \\
\text { контроль, \% }\end{array}$ \\
\hline Контроль 1 ГДК $C d$ & $0,41 \pm 0,039$ & - \\
\hline S. scrofa + 1 ГДК Cd & $0,57 \pm 0,142 *$ & 141,8 \\
\hline C. capreolus +1 ГДК Cd & $0,83 \pm 0,082 *$ & 205,8 \\
\hline Контроль 5 ГДК Cd & $0,62 \pm 0,109$ & - \\
\hline S. scrofa + 5 ГДК Cd & $0,38 \pm 0,041^{*}$ & 61,5 \\
\hline C. capreolus +5 ГДК Cd & $0,57 \pm 0,071$ & 92,3 \\
\hline Контроль 10 ГДК $C d$ & $1,97 \pm 0,287$ & - \\
\hline S. scrofa + 10 ГДК Cd & $0,97 \pm 0,179 *$ & 49,4 \\
\hline C. capreolus +10 ГДК Cd & $1,00 \pm 0,188^{*}$ & 50,6 \\
\hline $\begin{array}{l}\text { Контроль (ділянка без } C d \\
\text { та екскрецій ссавців) }\end{array}$ & $1,61 \pm 0,179$ & - \\
\hline Контроль 1 ГДК Cd & $0,41 \pm 0,039 *$ & 25,0 \\
\hline Sus scrofa + 1 ГДК Cd & $0,57 \pm 0,142^{*}$ & 35,3 \\
\hline C. capreolus +1 ГДК Cd & $0,83 \pm 0,082 *$ & 51,5 \\
\hline Контроль 5 ГДК $C d$ & $0,62 \pm 0,109^{*}$ & 38,2 \\
\hline S. scrofa + 5 ГДК Cd & $0,38 \pm 0,041^{*}$ & 23,5 \\
\hline C. capreolus +5 ГДК Cd & $0,57 \pm 0,071^{*}$ & 30,8 \\
\hline
\end{tabular}

Примітка: див. табл. 1.

Вплив комбінованої дії екскрементів ссавців

Таблиця 3 та Сd на вміст білків водорозчинної фракції в листках $G$. hederacea

\begin{tabular}{|c|c|c|}
\hline Варіант досліду & $\mathrm{x} \pm \mathrm{SD}$ & $\begin{array}{c}\text { Дослід/ } \\
\text { контроль, \% }\end{array}$ \\
\hline Контроль 1 ГДК $C d$ & $1,47 \pm 0,049$ & - \\
\hline S scrofa +1 ГДК Cd & $1,35 \pm 0,038^{*}$ & 89,9 \\
\hline C. capreolus +1 ГДК Cd & $1,48 \pm 0,145$ & 100,2 \\
\hline Контроль 5 ГДК $C d$ & $1,33 \pm 0,076$ & - \\
\hline S. scrofa + 5 ГДК Cd & $1,31 \pm 0,120$ & 98,6 \\
\hline C. capreolus +5 ГДК Cd & $1,33 \pm 0,088$ & 100,3 \\
\hline Контроль 10 ГДК $C d$ & $2,50 \pm 0,103$ & - \\
\hline S. scrofa + 10 ГДК Cd & $1,61 \pm 0,145^{*}$ & 64,4 \\
\hline C. capreolus + 10 ГДК Cd & $1,33 \pm 0,144^{*}$ & 53,3 \\
\hline $\begin{array}{l}\text { Контроль (ділянка без } C d \\
\text { та екскрецій Mammalia) }\end{array}$ & $1,76 \pm 0,018$ & - \\
\hline Контроль 1 ГДК Cd & $1,47 \pm 0,049^{*}$ & 84,8 \\
\hline Sus scrofa + 1 ГДК Cd & $1,35 \pm 0,038^{*}$ & 76,6 \\
\hline C. capreolus +1 ГДК Cd & $1,48 \pm 0,145$ & 106,9 \\
\hline Контроль 5 ГДК $C d$ & $1,33 \pm 0,076^{*}$ & 65,4 \\
\hline S. scrofa +5 ГДК $C d$ & $1,31 \pm 0,120^{*}$ & 74,7 \\
\hline C. capreolus + 5 ГДК Cd & $1,33 \pm 0,088^{*}$ & 78,1 \\
\hline
\end{tabular}

Примітка: див. табл. 1.

Підвищення вмісту металу (5 ГДК Сd) на фоні внесення екскрецій як $S$. scrofa, так і $C$. capreolus також сприяли відновленню нітратного метаболізму відносно контролю (контроль 5 ГДК Сd), наближаючи до контрольного $\left(\mathrm{t}_{0,05}=0,07\right.$ та 0,02$)$. За умов дії тільки кадмію активність АЛТ була достовірно інгібована.
За 10 ГДК Cd екскреції $S$. scrofa порівняно 3 C. capreolus сприяли достовірному відновленню (на $10 \%)$ вмісту альбумінів до контрольного показника $\left(\mathrm{t}_{0,05}=\right.$ $2,76)$, тоді як на фоні внесення екскрецій $C$. capreolus активність АЛТ залишалася удвічі нижчою за контроль (контроль 10 ГДК Сd).

Вміст альбумінів достовірно $\left(\mathrm{t}_{0,05}=5,99,17,69,2,09\right.$, $2,10,3,60$ та 1,29) знижений майже для усіх варіантів досліду відносно контролю (ділянка без забруднення $\mathrm{Cd}$ та екскрецій ссавців), що доводить наявність подвійного стресу за умов комбінованої дії екскрементів ссаців і внесення даного металу (табл. 3).

Зареєстровано достовірну кореляцію $(\mathrm{r}=0,91)$ між активністю АЛТ і вмістом альбумінів за умов тільки впливу Cd у спектрі даних концентрацій. Кореляція між активністю АЛТ та водорозчинною фракцією білка за умов комбінованої дії Сd та екскрементів ссавців становила $\mathrm{r}=0,94$ (1 ГДК Cd), r =0,97 (5 ГДК Cd) та була відсутня за 10 ГДК Сd $(\mathrm{r}=0,15)$.

\section{Висновки}

Кадмій впливав на накопичення білків водорозчинної фракції в листках $G$. hederacea, знижуючи $\left(\mathrm{t}_{0,05}=\right.$ $1,64,1,96$ та 2,41) на $20 \%$ та $28 \%$ активність даного ензиму відносно контролю (ділянка без забруднення $\mathrm{Cd}$ та екскрецій ссавців). Сd в листках $G$. hederacea достовірно ( $\mathrm{P}<0,05)$ інгібував $\left(\mathrm{t}_{0,05}=1,98\right.$ та 2,80$)$ активність АЛТ для всіх варіантів досліду. Наявна кореляція $(\mathrm{r}=0,91)$ між активністю АЛТ і вмістом альбумінів.

За умов комбінованої дії $\mathrm{Cd}$ та екскрементів C. capreolus останні сприяли нормалізації активності АЛТ в листках G. hederacea до 205\% (на фоні 1 ГДК Сd) та наближенню до контрольних показників (на фоні 5 ГДК Сd). За умов внесення 10 ГДК Сd протекторної дії екскрементів C. capreolus відносно контролю (10 ГДК Cd) не виявлено. Екскреції $S$. scrofa сприяли підвищенню активності АЛТ до 141\% (на фоні 1 ГДК Сd), ефект нормалізації стресу від концентрацій $\mathrm{Cd} 5$ та 10 ГДК не спостерігався. Вміст альбумінів наближався до контрольного показника за даної концентрації $\mathrm{Cd}$ (1 та 5 ГДК) відносно відповідних контролів (контроль 1 ГДК Сd та 5 ГДК Сd).

Між активністю АЛТ та водорозчинною фракцією білка за умов комбінованої дії $\mathrm{Cd}$ та екскрементів ссавців кореляція становила $\mathrm{r}=0,94$ (1 ГДК Сd), $\mathrm{r}=0,97$ (5 ГДК Сd); за 10 ГДК Сd кореляція булла недостовірною $(\mathrm{r}=0,15)$.

\section{Бібліографічні посилання}

Boshoff, M., Jonge, M.D., Scheifler, R., Bervoets, L., 2014. Predicting As, $\mathrm{Cd}, \mathrm{Cu}, \mathrm{Pb}$ and $\mathrm{Zn}$ levels in grasses (Agrostis $s p$. and Poa sp.) and stinging nettle (Urtica dioica) applying soil - plant transfer models. Sci. Total. Environ. 493(15), 862-871.

Bradford, M., 1976. A rapid and sensitive method for the quantification of microgram quantities of protein utilising the principle of protein-dye binding. Anal. Biochem. 72, 248-254.

Dospekhov, B.A., 1985. Metodika polevogo opyta [Methods of experience of the field]. Agroprom Press, Moscow (in Russian). 
Fuller-Espie, S.L., Bearoff, F.M., Minutillo, M.A., 2011. Exposure of coelomocytes from the earthworm Eisenia hortensis to $\mathrm{Cu}, \mathrm{Cd}$, and dimethylbenz[a]anthracene: An in vitro study examining reactive oxygen species production and immune response inhibition. Pedobiologia 54(29), S31-S36.

Hameed, A., Mahmooduzzafar, T.N.Q, Siddiqi, T.O., Iqbal, M., 2011. Differential activation of the enzymatic antioxidant system of Abelmoschus esculentus L. under $\mathrm{CdCl}_{2}$ and $\mathrm{HgCl}_{2}$ exposure. Braz. J. Plant Physiol. 23(1), 46-54.

Hasan, S.A., Hayat, S., Wani, A.S, Ahmad, A., 2011. Establishment of sensitive and resistant variety of tomato on the basis of photosynthesis and antioxidative enzymes in the presence of cobalt applied as shotgun approach. Braz. J. Plant Physiol. 23(3), 175-185.

Has-Schön, E., Bogut, I., Vuković, R., Galović, D., Bogut, A., Horvatić, J., 2015. Distribution and age-related bioaccumulation of lead $(\mathrm{Pb})$, mercury $(\mathrm{Hg})$, cadmium $(\mathrm{Cd})$, and arsenic (As) in tissues of common carp (Cyprinus carpio) and European catfish (Sylurus glanis) from the Buško Blato reservoir (Bosnia and Herzegovina). Chemosphere 135, 289-296.

Joshi, G., Shukla, A., Shukla, A., 2011. Synergistic response of auxin and ethylene on physiology of Jatropha curcas L. Braz. J. Plant Physiol. 23(1), 66-77.

Kobyletska, M., Terek, O., 2002. Vplyv ioniv kadmiiu na vmist fenolnykh spoluk ta vilnoho prolinu v roslynakh kukurudzy [The impact of cadmium ions on the content of phenolic compounds and free proline in maize plants]. Visn. Lviv. Univ. Ser. Biol. 28, 311-316.

Kuta, E., Jędrzejczyk-Korycińska, M., Cieślak, E., Rostański, A, Szczepaniak, M., Migdałek, G, Wąsowicz, P., Suda, J., Combik, M., Słomka, A., 2014. Morphological versus genetic diversity of Viola reichenbachiana and $V$. riviniana (sect. Viola, Violaceae) from soils differing in heavy metal content. Plant Biol. 16(5), 924-934.

Li, Z.H., Chen, L., Wu, Y.H., Li, P., 2014. Effects of mercury on oxidative sand gene expression of potential biomarkers in larvae of the Chinese rare minnow Gobiocypris rarus. Environ. Contam. Toxicol. 67(2), 245-251.

Páez-Osuna, F., 2015. Bioavailability of cadmium, copper, mercury, lead, and zinc in subtropical coastal lagoons from the southeast Gulf of California osing mangrove oysters (Crassostrea corteziensis and Crassostrea palmula). Environ. Contam. Toxicol. 68(2), 305-316.

Pakhomov, A.Y., Vasilyuk, O.M., 2012. Aktyvinst' fermentiv pereaminuvannya yak indykator seredovyshchetvirnoyi funktsiyi Mammalia v transformovanykh ekosystemakh [Activity of transamination enzymes as the indicator of environmantal forming function of Mammalia representatives in transformed antropogenic ecosystem]. Sci. Vis. Cher. Univ. Ser. Biol. System. 4(4), 455-462.

Polevoy, V., Maximov, G. (ed.), 1978. Metody biohimicheskogo analiza rastenij [Methods of analysis biochemically of plants]. Leningrad Univ. Press, Leningrad (in Russian).

Rau, S., Miersch, J., Neumann, D., Weber, E., Krauss, G.-J., 2007. Biochemical responses of the aquatic moss Fontinalis antipyretica to $\mathrm{Cd}, \mathrm{Cu}, \mathrm{Pb}$ and $\mathrm{Zn}$ determined by chlorophyll fluorescence and protein levels. Environ. Exp. Bot. 59(3), 299-306.

Shamim, S., Rehman, A., 2014. Cadmium-resistance mechanism in the bacteria Cupriavidus metallidurans CH34 and Pseudomonas putida mt2. Environ. Contam. Toxicol. 67(2), 149-157.

Song, Y.F., Luo, Z., Pan, Y.X., Liu, X., 2014. Effects of copper and cadmium on lipogenic metabolism and metal element composition in the javelin goby (Synechogobius hasta) after single and combined exposure. Environ. Contam. Toxicol. 67(2), 167-180.

Vasilyuk, O.M., Pakhomov, A.Y., 2012. Vplyvi ioniv nikelju na funkcional'nu aktyvnist' transaminaz v lystkah Glechoma hederatia L. v umovahryjnoi' aktyvnosti Mammalia [Effect of nickel ions on the functional activity of enzymes in the leaves of Glechoma hederatia L. in digging activity of Mammalia]. Achievement of High school-2012: Materialy VIII Mezhdunarodnoj Nauchno-Prakticheskoj Konferencii. Bjal GRAD-BG, Sofija, 21, 43-49 (in Ukrainian).

Vasilyuk, O.M., Pakhomov, A.Y., 2014. Effect of lead ions on alanine aminotransferase activity in Glechoma hederacea leaves subject. Scientific Enquiry in the Contemporary World: Theoretical basics and innovative approach. Colloquium, California, USA, 19-26.

Wang, J., Li, W., Zhang, C., Ke, S., 2010. Physiological responses and detoxific mechanisms to $\mathrm{Pb}, \mathrm{Zn}, \mathrm{Cu}$ and $\mathrm{Cd}$ in young seedlings of Paulownia fortunei. J. Environ. Sci. 22(12), 1916-1922.

Weyens, N., Gielen, M., Beckers, B., Boulet, J., van der Lelie, D., Taghavi, S., Carleer, R., Vangronsveld, J., 2014. Bacteria associated with yellow lupine grown on a metalcontaminated soil: In vitro screening and in vivo evaluation for their potential to enhance Cd phytoextraction. Plant Biol. 16(5), 998-996.

Wu, F.Y., Bi, Y.L., Leung, H.M., Ye, Z.H., Lin, X.G., Wong, M.H., 2010. Accumulation of $\mathrm{As}, \mathrm{Pb}, \mathrm{Zn}, \mathrm{Cd}$ and $\mathrm{Cu}$ and arbuscular mycorrhizal status in populations of Cynodon dactylon grown on metal-contaminated soils. Appl. Soil Ecol. 44(3), 213-218.

Надійшла до редколегї 22.06.2015 